\title{
Necrosis Is the Predominant Type of Islet Cell Death During Development of Insulin-Dependent Diabetes Mellitus in BB Rats
}

\author{
Karin Fehsel, Victoria Kolb-Bachofen, and Klaus-Dietrich Kröncke \\ Research Group Immunobiology, Department of Medicine, Heinrich-Heine-University of Düsseldorf, \\ Düsseldorf, Germany
}

\begin{abstract}
SUMMARY: Several reports propose that apoptosis of pancreatic beta cells may play a central role in the pathogenesis of both spontaneous and induced insulin-dependent diabetes mellitus (IDDM) in animal models. Whether apoptosis is a major cell death pathway during diabetes development, however, is highly controversial. The aim of this study was to examine the mode of islet cell death in prediabetic diabetes-prone (dp) BB rats, which spontaneously develop diabetes and serve as an animal model for human IDDM. In addition we investigated the cell death pathway of islet cells treated with the widely used diabetogenic compound streptozotocin or with nitric oxide (NO), which during IDDM development has been found to be present in inflamed islets in high concentrations because of the expression of inducible NO synthase. Islets of prediabetic BBdp rats were analyzed for DNA strand breaks and screened by electron microscopy. The mode of islet cell death in vitro after treatment with cytotoxic concentrations of streptozotocin or of $\mathrm{NO}$ was investigated using different methods including morphologic analysis by electron microscopy, detection of DNA strand breaks, poly(ADP-ribose) polymerase cleavage, and annexin $\mathrm{V}$ staining. Although cells with DNA stand breaks - often accepted as a proof for apoptosis-could be identified, we did not find apoptosis-specific features during islet cell death. Instead we observed massive necrosis as evidenced by disrupted plasma membranes and spilled-out cellular constituents in vitro as well as during disease manifestation in BBdp rats. These results may have serious consequences with regard to the treatment of humans to prevent the development of IDDM. (Lab Invest 2003, 83:549-559).
\end{abstract}

\section{$I$} $\mathrm{n}$ humans, insulin-dependent diabetes mellitus (IDDM) results from a progressive and irreversible islet cell loss during a preceding asymptomatic period that may start many years before clinical onset. Studies on animal models of IDDM-the BB rat and the nonobese diabetic mouse-revealed that cells of the innate and the adoptive immune system are involved in islet cell destruction. Two distinct modes of cell death, apoptosis or necrosis, can be distinguished because of differences in morphologic, biochemical, and molecular changes. During necrosis, cells swell and lyse. The cell content is released in an uncontrolled manner into the surrounding tissue and attracts immune cells, leading to inflammatory reactions (Fig. 1). In contrast, apoptosis is characterized by a sequence of events ultimately leading to cell fragmentation into small apoptotic bodies, thus minimizing leakage of cellular contents and inflammation (Fig. 1). In intact tissues, neighboring cells or phagocytes will engulf and degrade these apoptotic bodies. Only during massive local apoptosis, cells may be unable to

DOI: 10.1097/01.LAB.0000063927.68605.FF

Received January 15, 2003.

Address reprint requests to: Dr. K.-D. Kröncke, Research Group Immunobiology 23.12, Medical Department, Heinrich-Heine-University of Düsseldorf, Universitätsstr. 1, D-40225 Düsseldorf, Germany. E-mail: kroencke@uni-duesseldorf.de cope with the load of fragments and secondary necrosis may occur.

There are several reports indicating islet cell death via apoptosis after treatment with proinflammatory cytokines (Ankarcrona et al, 1994; Delaney et al, 1997; Dunger et al, 1996; Iwahashi et al, 1996; Saldeen, 2000; Trincavelli et al, 2002), streptozotocin (Sz) (Morgan et al, 1994; Saini et al, 1996), or nitric oxide (NO) donors (Di Matteo et al, 1997; Kaneto et al, 1995). However, in most cases, islet cell lines were used and/or detection of DNA strand breaks or light microscopical analysis was taken as proof of apoptosis. After screening of pancreata of murine diabetes animal models by morphologic analysis via light microscopy or by methods to detect DNA strand breaks on tissue sections, islet cell apoptosis has been suggested to occur in these animals (Augstein et al, 1998; Cardinal et al, 2001; George et al, 2002; Hill et al, 1999; Kurrer et al, 1997; Lally et al, 2001; O’Brien et al, 1996, 1997). In contrast, in mice treated with low-dose $\mathrm{Sz}$, analysis by electron microscopy showed necrosis to be the dominant or even sole mode of islet cell death (Aughsteen, 2000; Kolb-Bachofen et al, 1988; Like et al, 1978; Papaccio et al, 1991), and apoptosis was found only in infiltrating lymphocytes (SainioPöllänen et al, 1998). It is thus unclear whether islet cell death during IDDM development occurs by necrosis, by apoptosis, or by a combination of both (Eizirik and Darville, 2001; Mauricio and Mandrup-Poulsen, 1998; Pipeleers et al, 2001). 


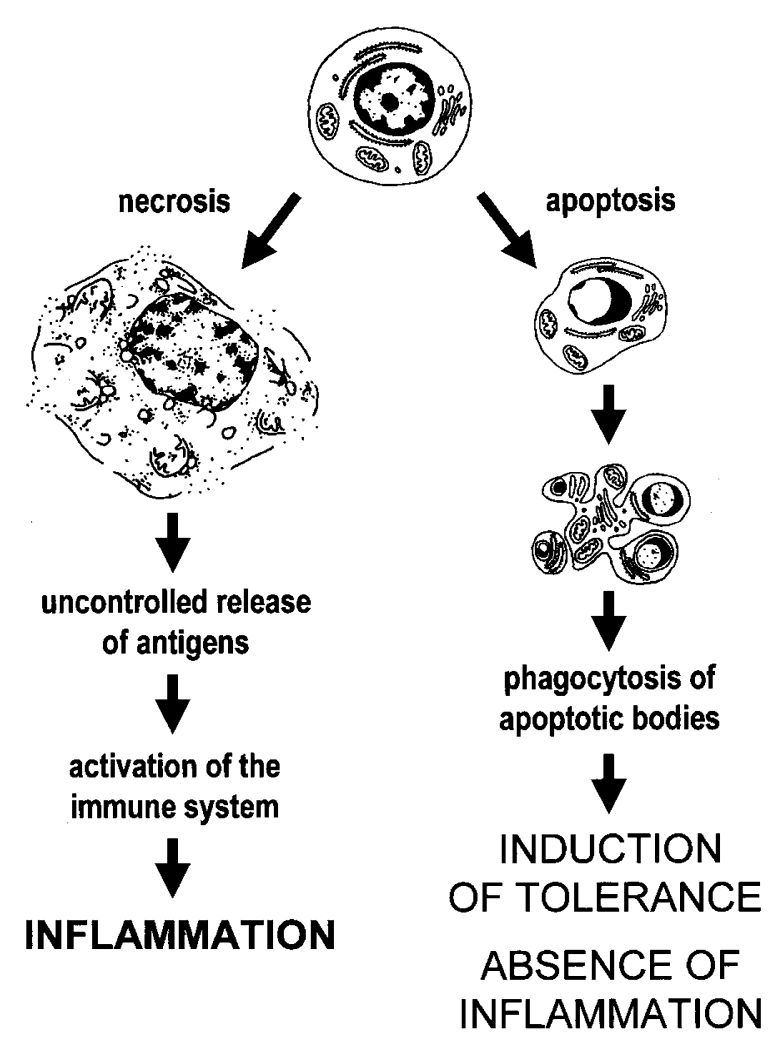

Figure 1.

Scheme representing the two death pathways necrosis and apoptosis (modified from Kerr, 1995). Necrosis is characterized by cell swelling, plasma membrane damage, and loss of cytoplasmic contents into the extracellular space, which leads to uncontrolled presentation of antigens to the immune system and may cause inflammatory reactions. In contrast, apoptotic cells shrink while retaining intact plasma membranes. Their cellular contents are packaged into apoptotic bodies that subsequently will be phagocytosed by neighboring cells or by professional phagocytes. Usually, the apoptotic cell death pathway does not lead to inflammation.

Because the type of cell death may define the strategy to prevent IDDM, we investigated the mode of islet cell death in prediabetic diabetes-prone (dp) BB rats. In addition, we searched for apoptotic features during cell death of rat islet cells that was induced by $\mathrm{Sz}$ or by the NO donor S-nitroso-N-acetyl-D,Lpenicillamine (SNAP), mimicking inducible NO synthase activity.

\section{Results}

\section{Mode of Islet Cell Death During Disease Manifestation in BBdp Rats}

Pancreata of 20 prediabetic BBdp rats (9 rats, 35-40 days of age; 6 rats, 41-49 days; 5 rats, 50-60 days) were investigated by light microscopy after visualization of DNA fragmentation by in situ nick translation. A total of 203 islets were analyzed. In BBdp rats 35 to 40 days of age, no cells with DNA strand breaks could be identified. In the 41- to 49-day-old BBdp rats and in the 51- to 60-day-old BBdp rats, one islet and seven islets, respectively, were found containing single cells positively staining for DNA strand breaks (Fig. 2A). As a positive control, islets of mice treated with a high dose of the diabetogenic compound $\mathrm{Sz}(200 \mathrm{mg} / \mathrm{kg}$ body weight) were used. Investigating 25 islets from pancreata of 2 animals, intensive DNA strand breaks were found in nearly all $\beta$ cells, and staining was restricted to the islets (Fig. 2B). Staining by the TUNEL technique (terminal deoxynucleotidyl transferasemediated dUTP nick-end labeling) yielded virtually identical results (data not shown). Because DNA strand breaks may point to ongoing apoptosis, islet cell morphology during diabetes development in BBdp rats was examined by electron microscopy. Pancreatic islets from 17 prediabetic BBdp rats (3 rats, 60 days of age; 5 rats, 65 days; 4 rats, 66 days; 5 rats, 69 days) with various stages of islet infiltration were screened. Examining 63 islets containing more than 3000 islet cells, only one single islet $\beta$ cell with a nucleus of apparent apoptotic morphology was found (Fig. 3D). In addition, 19 apoptotic nuclei were identified. However, these nuclei were mostly phagocytosed by macrophages, and nuclear morphology points to lymphocytes (Figs. 3, B and C). In contrast, large areas of lysed islet cells were found in islets infiltrated by immunocytes (Fig. 3A). Disrupted plasma membranes, loss of cytoplasmic electron contrast, and leakage of cellular constituents point to necrosis as the mode of islet cell death (Figs. 4, A to C). These results show that necrosis is by far the predominant cell death pathway in BBdp rats during disease development.

\section{Morphologic Analysis of Islet Cells Treated with Sz or NO In Vitro}

To investigate whether dying adult rat islet cells may show apoptotic features, we performed a series of in vitro investigations. Electron microscopic analysis of islet cells $(n=638)$ after long-term treatment (7 days) with $5 \mu \mathrm{g} / \mathrm{ml}$ cycloheximide ( $\mathrm{CHX}$ ) showed few $(1.4 \%)$ intact $\beta$ cells with clear-cut apoptotic nuclear morphology (Fig. 5C). However, the majority of the cells $(63.8 \%)$ showed lysis, often exhibiting condensed nuclei indicative of apoptosis and subsequent secondary necrosis. These results confirm that primary rat islet cells are indeed capable of performing an apoptotic cell death program (Hoorens et al, 1996). Treatment of islet cells with increasing concentrations of $\mathrm{Sz}$ or of the NO donor SNAP (0.1-1 mM each) for 15 hours resulted in concentration-dependent lysis (1 mM Sz: 99.6\% dead cells, $n=1581$; 1 mm SNAP: $100 \%$ dead cells, $n=1018$ ). At all of the concentrations used, nonviable islet cells were swollen, showing disrupted plasma membranes and decreased cytoplasmic electron contrast caused by loss of cell constituents (Fig. 5, A and B). Islet cells with the typical apoptotic nuclear morphology as found after $\mathrm{CHX}$ treatment were not detected. We also examined whole rat islets treated with Sz or with SNAP. To prevent loss of dead cells, the islets were encapsulated in small alginate beads before treatment. Encapsulated islets cultured in the absence of Sz or SNAP for 24 hours showed 

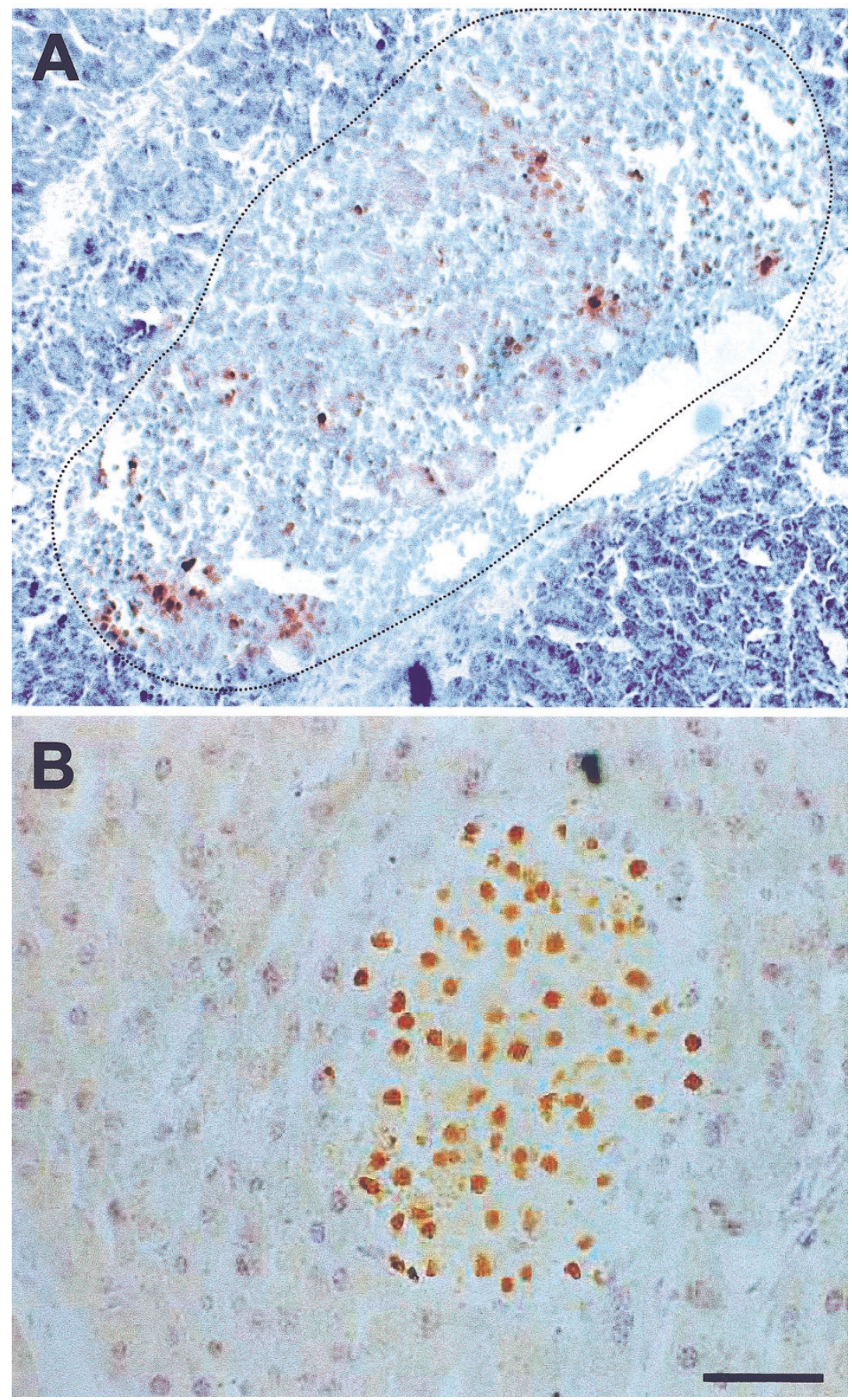

\section{Figure 2.}

Detection of in vivo DNA strand breaks. Islets of prediabetic BBdp rats (A) or of C57/BL6 mice injected with a high dose (200 mg/kg body weight) of streptozotocin (Sz) (B) were investigated. Islets of prediabetic BBdp rats (50-60 days old) showed single cells staining for DNA strand breaks. A, An islet of a 60-day-old BBdp rat. In contrast, nearly all islet cells in the high-dose Sz mice showed intense labeling for DNA strand breaks 15 hours after Sz injection, with staining being found exclusively within the islets (B). Bar represents $50 \mu \mathrm{m}$.

only single necrotic cells, similar to results published previously (Wiegand et al, 1993). In contrast, large areas of lysed necrotic $\beta$ cells were found after treatment with $0.5 \mathrm{~mm} \mathrm{Sz} \mathrm{(Fig.} \mathrm{5E)} \mathrm{or} \mathrm{with} 1 \mathrm{~mm}$ SNAP (not shown) for 24 hours. A few cells with apoptotic morphology were always located near or within capillaries (Fig. 5D), but because of morphology and lack of hormone-containing vesicles, none of them appeared to be an endocrine islet cell.

\section{Analysis of DNA Strand Breaks}

To analyze whether DNA strand breaks can be found during necrosis, DNA isolated from islet cells treated with cytotoxic $\mathrm{Sz}$ or NO concentrations for 3 or 5 hours was isolated and labeled by in situ nick translation. Visualization of the isolated DNA after gel electrophoresis confirmed that similar amounts of DNA were loaded (Fig. 6A). Southern blotting and 


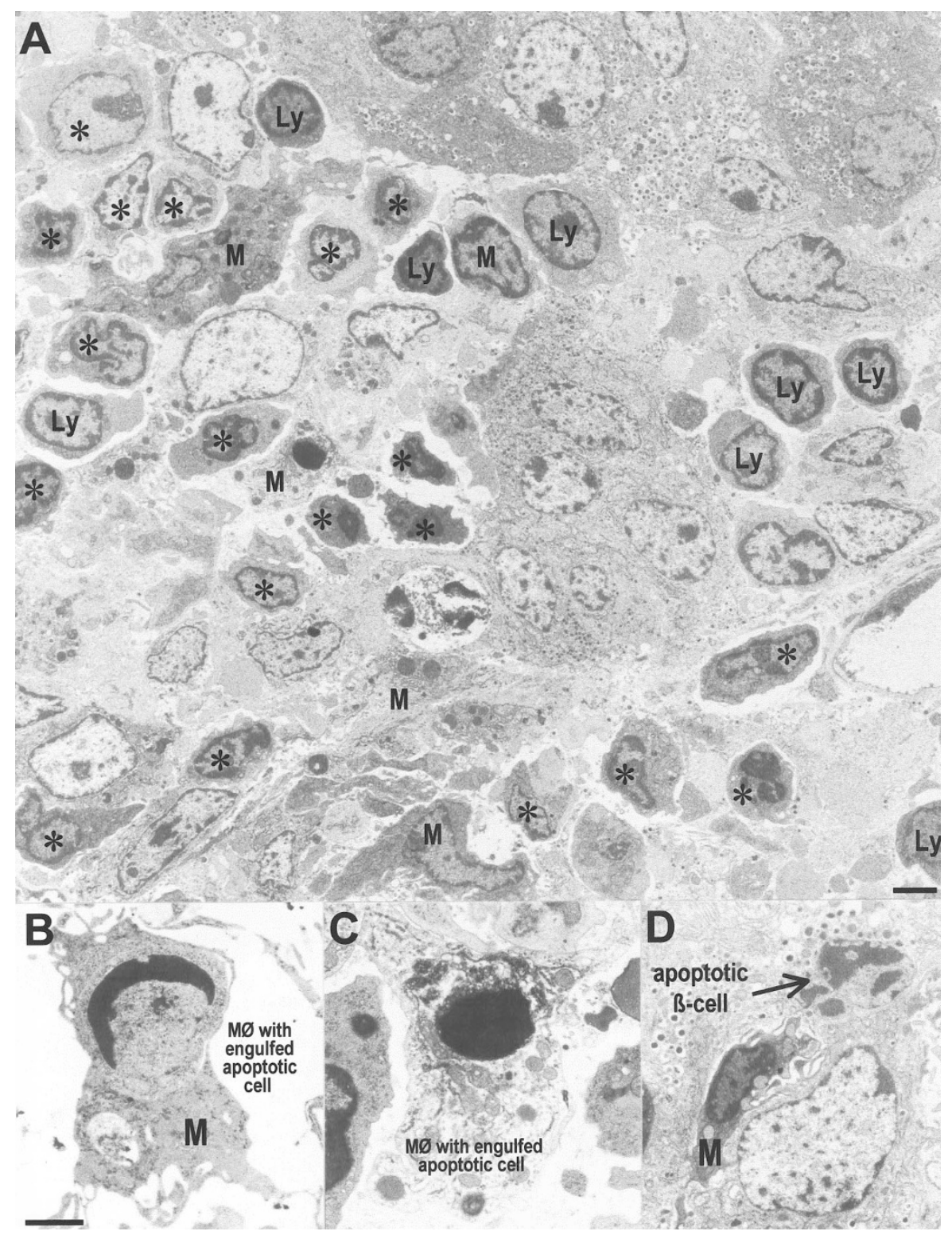

Figure 3.

Electron micrographs of prediabetic BBdp rat islets. Rats were 60 (A and C), 65 (B), or 69 (D) days old. Large areas of lysed islet cells and numerous infiltrating macrophages $(M)$, lymphocytes $(L y)$ and unidentified nonendocrine cells $\left({ }^{*}\right)$ were found $(A)$. Occasionally, apoptotic bodies with highly condensed chromatin were detected. Higher magnifications show that these apoptotic bodies were phagocytosed by infiltrating macrophages (B and C). Only one single $\beta$ cell with apoptosis-like morphology was detected after examining more than 3000 islet cells (D). Bars represent $2 \mu \mathrm{m}(A)$ or $1 \mu \mathrm{m}$ (B to D).

staining for incorporated biotin-dUTP to quantify DNA strand breaks showed that DNA from islet cells treated with $1 \mathrm{~mm} \mathrm{Sz}$ for 3 hours was strongly stained but remained at a high molecular weight, indicative of single-strand break formation during DNA excision repair (Fig. 6B). DNA of islet cells treated with $1 \mathrm{~mm}$ SNAP for 3 hours was weakly stained and still found to be of high molecular weight. However, with longer incubation times, staining for DNA strand breaks increased. Additionally, a significant shift from high molecular to lower molecular weights was found, indicative of ongoing DNA fragmentation. Absence of the typical DNA ladder as a characteristic feature of apoptosis argues against $\mathrm{Sz}$ - or NO-induced apoptosis.

\section{Analysis of PARP Cleavage}

Caspase-3-mediated cleavage of the enzyme poly(ADP-ribose) polymerase (PARP) represents a prominent early event during apoptosis (Nicholson et al, 1995; Tewari et al, 1995). We therefore searched for the presence of PARP fragments after treatment of islet cells with cytotoxic NO concentrations. Thymocytes treated with the topoisomerase II inhibitor etoposide (Eto) served as a positive control. Western blot analysis showed that treatment of thymocytes with 50 $\mu \mathrm{M}$ Eto for 8 hours resulted in complete PARP cleavage as an indication of caspase-3-mediated apoptosis (Fig. 7). In contrast, the 116-kDa band of intact PARP detected in lysates of islet cells treated with 1 

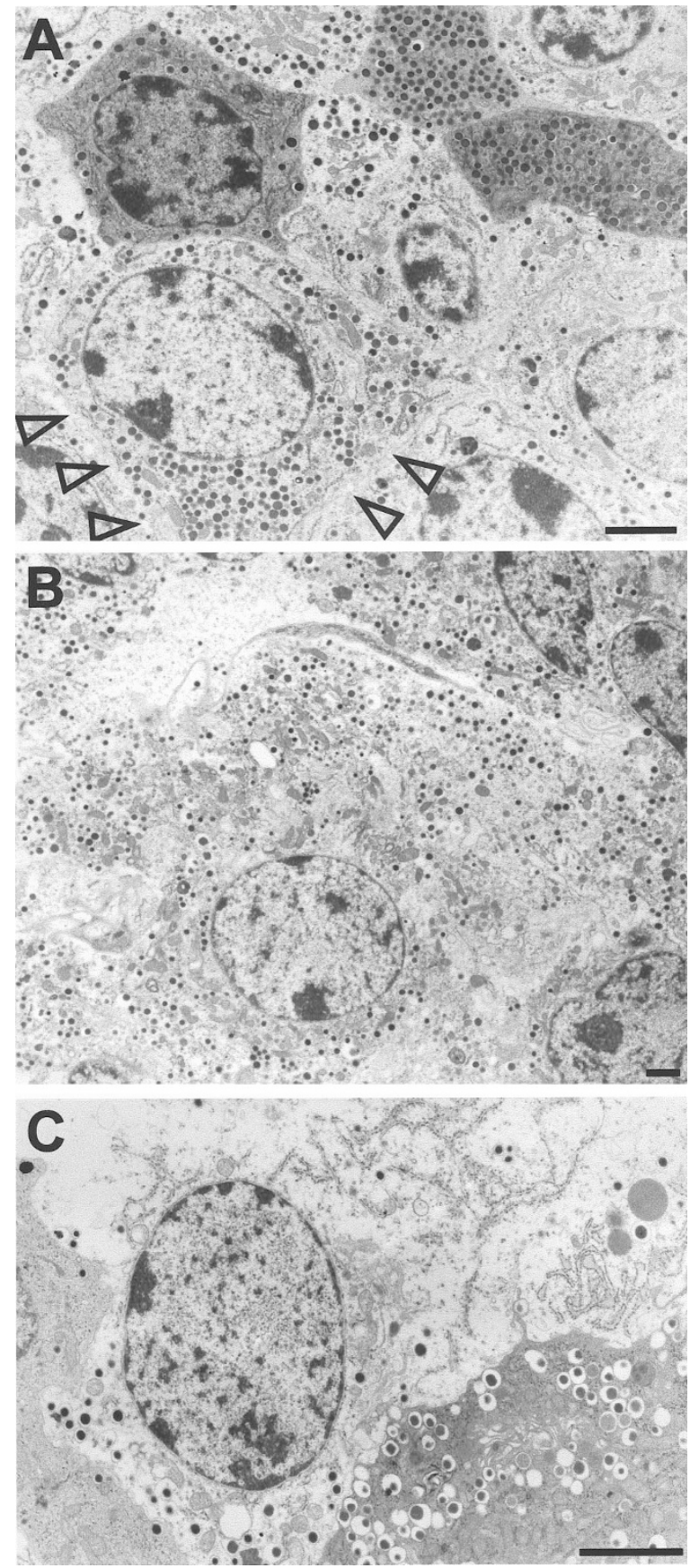

\section{Figure 4.}

High-powered electron micrographs of necrotic islet cells found in islets of prediabetic BBdp rats. Rats were 65 (A), 66 (B), or 69 (C) days old. Islet cell plasma membranes are disrupted (arrowheads in $\mathrm{A}$ ), and the cytoplasmic contents released into the surrounding tissue indicate necrosis (B and $C$ ). Morphology of islet cell nuclei shows no signs of chromatin condensation. Bars represent $2 \mu \mathrm{m}$.

mM SNAP for 15 hours was even stronger compared with untreated islet cells. No PARP fragments could be detected, pointing to the absence of NO-induced apoptosis in islet cells.

\section{Annexin-V Staining}

During early phases of apoptosis, phosphatidylserine residues are translocated from the inner to the outer
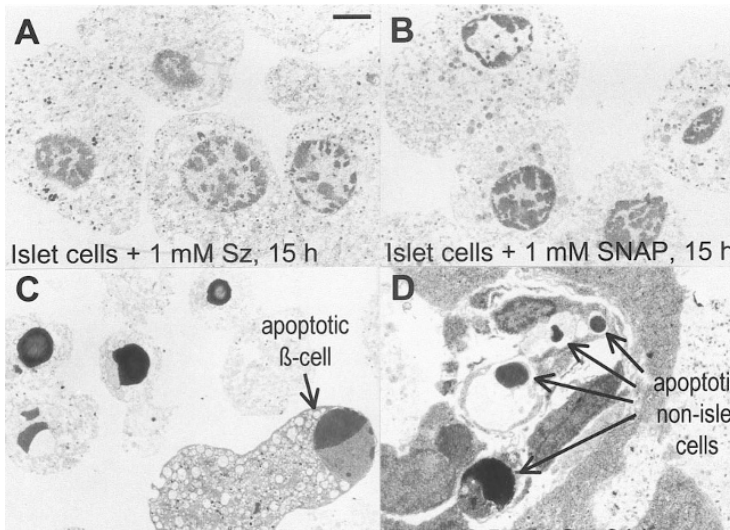

Islet cells $+5 \mu \mathrm{g} / \mathrm{ml} \mathrm{CHX}, 7 \mathrm{~d}$

E

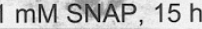

lysed necrotic islet cells

$\mathrm{mM} \mathrm{Sz}, 24$

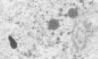

D
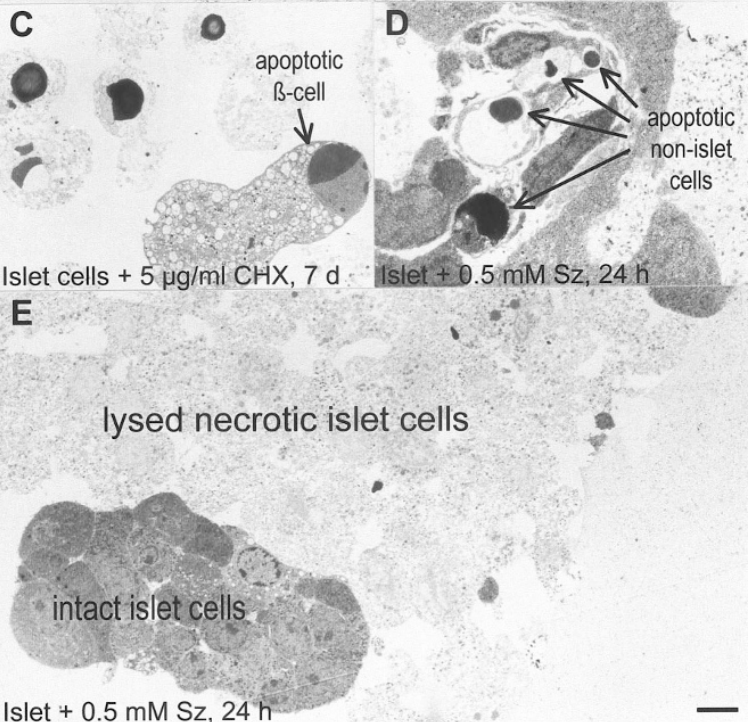

Islet + $0.5 \mathrm{mM} \mathrm{Sz}, 24 \mathrm{~h}$

\section{Figure 5.}

Electron microscopic characterization of necrotic and apoptotic islet cells. Treating isolated islet cells with $1 \mathrm{~mm} \mathrm{Sz} \mathrm{(A)} \mathrm{or} \mathrm{with} 1 \mathrm{~mm}$ of the nitric oxide (NO) donor S-nitroso-N-acetyl-D,L-penicillamine (SNAP) (B) for 15 hours resulted in a necrotic mode of cell death as characterized by swollen cells, loss of cytoplasmic electron contrast, and nuclei devoid of chromatin condensation. In contrast, treatment of isolated islet cells with $5 \mu \mathrm{g} / \mathrm{ml} \mathrm{CHX}$ for 7 days yielded apoptotic as well as lysed islet cells containing nuclei with condensed chromatin, indicative of apoptosis followed by secondary necrosis (C). Treatment of alginate-encapsulated whole rat islets with $0.5 \mathrm{~mm} \mathrm{Sz}$ for 24 hours resulted in massive necrosis of the $\beta$ cells with only small regions of intact non $\beta$-islet cells at the rims of the islets $(\mathrm{E})$. The only apoptotic cells detected were nonendocrine islet cells near or within islet capillaries, probably endothelial or duct cells (D). Bars represent $2.5 \mu \mathrm{m}$ (A to D) or $5 \mu \mathrm{m}(\mathrm{E})$.

surface of the plasma membrane and can be detected by fluorescent annexin $\mathrm{V}$ binding. Simultaneous staining with propidium iodide $(\mathrm{PI})$ and quantitation by flow cytometry was performed to analyze early events during islet cell death induced by cytotoxic Sz or NO concentrations. As a positive control for apoptosis, thymocytes were incubated with Eto, and as a control for necrosis, with formaldehyde (Fearnhead et al, 1994). Compared with untreated thymocytes (Fig. 8D), treatment with $50 \mu \mathrm{M}$ Eto for 6 hours (Fig. 8E) resulted in a significant shift to annexin $\mathrm{V}$-positive staining (quadrant 4) plus a significant shift to dual staining (quadrant 2) because of permeable plasma membranes, which led to the intracellular accessibility of phosphatidylserines for annexin V-binding as a consequence of primary or secondary necrosis (Fig. 8E). In contrast, lysis of thymocytes by formaldehyde only induced a shift toward quadrant 2 (Fig. 8F). Compared with untreated islet cells (Fig. 8A), treatment with $1 \mathrm{~mm}$ $\mathrm{Sz}$ for 6 hours (Fig. 8B) or for 12 hours (not shown) only led to a significant shift toward quadrant 2 , indicative of necrosis, whereas treatment with $1 \mathrm{mM}$ SNAP for 6 


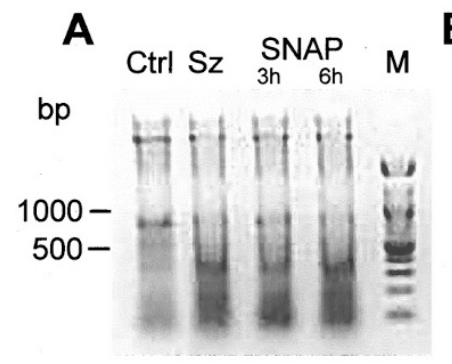

B

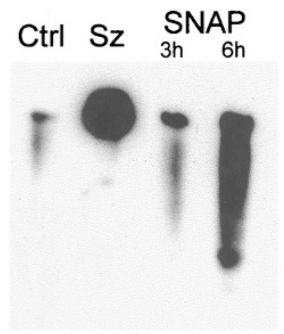

Figure 6 .

Analysis of DNA strand breaks after treatment of islet cells with Sz or NO. DNA was isolated from $4 \times 10^{4}$ islet cells cultured in the absence or presence of 1 $\mathrm{mm} \mathrm{Sz}$ for 3 hours or of $1 \mathrm{~mm}$ of the NO donor SNAP for 3 and 5 hours, respectively, and labeled by in situ nick translation. For calibration, a DNA size marker $(M)$ was included. A, DNA staining by ethidium bromide was performed to show that similar amounts of DNA were loaded. B, Southern blot of $A$ and subsequent labeling for DNA strand breaks. DNA of Sz-treated islet cells showed intense nick labeling but was of high molecular weight, indicative of single-strand breaks. DNA isolated from SNAP-treated islet cells showed weak nick labeling after 3 hours and intense nick labeling after 5 hours with a shift from high to low molecular weight DNA, indicative of ongoing DNA doublestrand breaking.

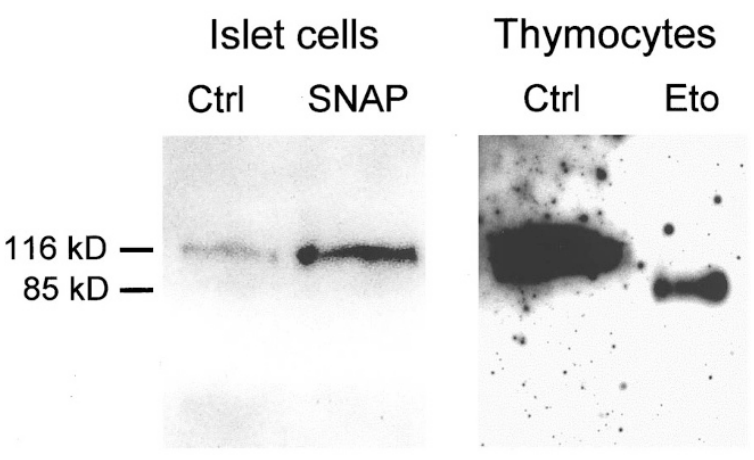

\section{Figure 7.}

Analysis of poly(ADP-ribose) polymerase (PARP) cleavage. Islet cells $\left(10^{6}\right)$ were cultured in the absence (Ctrl) or presence of $1 \mathrm{~mm}$ of the NO donor SNAP for 15 hours. Thymocytes $\left(10^{6}\right)$ treated with $50 \mu \mathrm{m}$ etoposide (Eto) for 8 hours served as a positive control. Cells were lysed, and after run on $8 \%$ polyacrylamide gels, electrophoretic transfer of the separated proteins to nylon membranes was performed. Staining with amido black confirmed that comparable amounts of proteins were loaded in the respective lanes (not shown). Subsequently, the blots were stained using PARP antiserum and peroxidaseconjugated secondary antibodies. With islet cells, visualization of antibody binding to PARP revealed only one band at $116 \mathrm{kDa}$, which corresponds to uncleaved PARP. In contrast, in thymocytes treated with Eto, PARP is completely cleaved.

hours did not result in any significant shift (Fig. 8C). Thus, annexin $V$ staining experiments do not point to early apoptotic events in islet cells after treatment with cytotoxic concentrations of $\mathrm{Sz}$ or NO.

\section{Discussion}

It is well established that there are two fundamentally different ways through which eukaryotic cells can die, namely by the active cell death program apoptosis or by necrosis, which is considered to be a passive process. During necrosis, cells swell, followed by disintegration of the plasma membrane integrity and subsequent loss of the cellular content into extracellular spaces (Fig. 1). In contrast, cells undergoing apoptosis display a characteristic pattern of structural changes in their nuclei, including extensive cleavage of their DNA into oligonucleosomal-length fragments, and chromatin condensation. Cells shrink, while the plasma membrane remains intact. Ultimately, the cell content is packaged into small apoptotic bodies (Fig. 1) that are phagocytosed, thus minimizing contact to surrounding tissues. Although necrosis usually provokes inflammation, conditions causing apoptosis are normally not associated with inflammatory reactions or cell-mediated immunity. In fact, anti-inflammatory and immunosuppressive effects of apoptotic cells as well as induction of tolerance have repeatedly been found (Barker et al, 1999; Fadok et al, 1998; Steinman et al, 2000; Voll et al, 1997).

Convincing results showing apoptotic islet cell death during neonatal development (Petrik et al, 1998; Scaglia et al, 1995) or in cultures of islet cell lines (Ankarcrona et al, 1994; Di Matteo et al, 1997; Kaneto et al, 1995; Morgan et al, 1994) suggest that apoptosis can be induced in islet cells or cell lines with a high proliferation rate. However, under certain conditions (eg, using double-stranded RNA plus either IL- $1 \beta$ or IFN- $\gamma$, thus mimicking viral infection [Liu et al, 2001; Scarim et al, 2001]; after incubation with free fatty acids [Lupi et al, 2002]; or after long-term treatment with CHX [Hoorens et al, 1996]) apoptotic cell death can also be induced in primary rat islet cells; this shows that indeed adult islet cells are able to undergo apoptosis in vitro. Since in situ nick translation or the TUNEL technique allows detection of DNA strand breaks at the single cell level, light microscopical identification of such cells is easy to perform using isolated cells or tissue sections. Based on DNA strand break detection on tissue sections or on morphologic investigations by light microscopy, evidence for apoptosis occurring in islets during disease development in IDDM animal models has repeatedly been reported (Augstein et al, 1998; Cardinal et al, 2001; George et al, 2002; Hill et al, 1999; Kurrer et al, 1997; Lally et al, 2001; O'Brien et al, 1996, 1997), suggesting a significant or even predominant role of apoptosis for IDDM manifestation. Apparent islet cell apoptosis mostly was described as a rare event; however, it was suggested that islet cell destruction may occur over weeks to months, and because apoptotic cells are cleared rapidly, very few apoptotic islet cells are likely to be observed at any given time point (Augstein et al, 1998). Investigating islets of prediabetic BBdp rats, we found single cells positively staining for DNA strand breaks before disease manifestation. However, analyzing more than 3000 islet cells in islets of 60 - to 69-day-old prediabetic BBdp rats by electron microscopy, $<1 \%$ of the islet comprising cells showed apoptotic features like condensed nuclei. Among these only one single cell was positively identified as a $\beta$ cell (Fig. 3D), while the others lacked the typical hormone-containing granules and, as judged by morphology, probably represent immunocytes, similar to results recently found in nonobese diabetic mice (Sainio-Pöllänen et al, 1998). Looking for necrosis we found a heterogenous picture. Some islets containing 

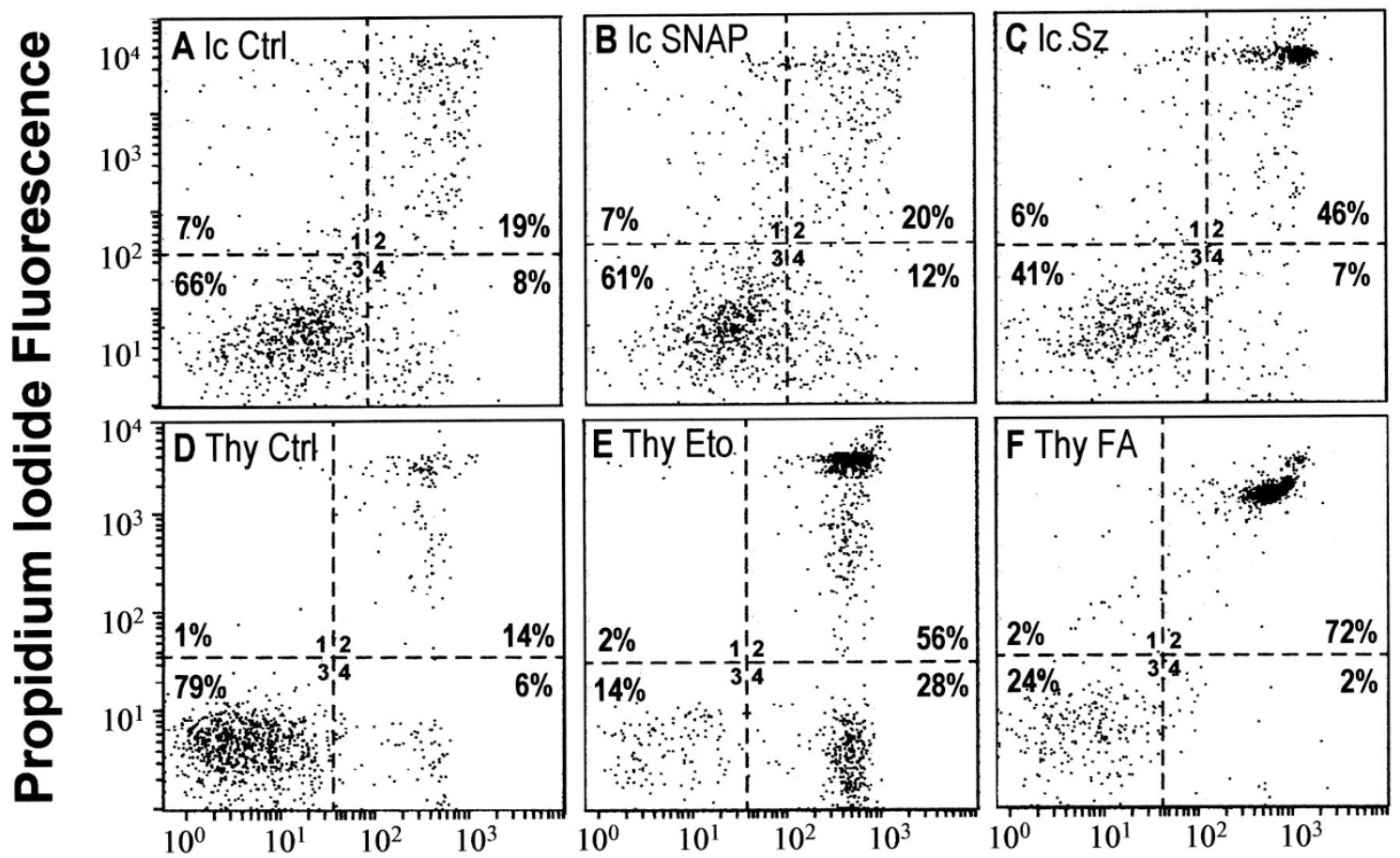

Annexin V-FITC Fluorescence

Figure 8.

Flow cytometric analysis of cells for annexin V binding. Gating of $10^{4}$ cells was performed with regard to propidium iodide (PI) and annexin V-FITC fluorescence. Background labeling of living cells is found in quadrant 3, whereas quadrant 4 contains apoptotic cells, stained with annexin V-FITC only. Necrotic cells in quadrant 2 are labeled by both PI and annexin V-FITC because of permeable plasma membranes. Compared with untreated isolated islet cells (A), culture in the presence of $1 \mathrm{~mm}$ Sz for 6 hours resulted in a significant shift toward a positive annexin V-FITC plus PI-stained cell population indicative of necrosis (B), whereas treatment with 1 mм SNAP for 6 hours did not induce any significant shift (C). As a control, apoptotic and necrotic thymocytes (Thy) were analyzed. Compared with untreated thymocytes (D), treatment with $50 \mu \mathrm{m}$ Eto for 6 hours resulted in a significant shift toward quadrant 4 (E), suggestive for apoptosis. Costaining with PI in quadrant 2 points to secondary necrosis or lysis as seen with thymocytes lysed by formaldehyde (F).

no immune cells seemed to be intact, others containing infiltrating cells showed large areas of lysed islet cells, and some islets were completely destroyed, showing cell debris only. Because of the lack of unequivocal or specific criteria for a necrotic cell death pathway, it is difficult to state the exact number of necrotic islet cells. However, our results clearly show that in heavily infiltrated islets, the vast majority of dead islet cells exhibit a typical necrotic morphology, ie, loss of plasma membrane integrity, decreased cytoplasm electron density, and spill-out of cytoplasmic components (Fig. 4, A to C). Thus, even if apoptosis may occur in single islet cells, the predominant mode of islet cell death during disease development in BBdp rats is certainly necrosis.

Although we found massive DNA damage in vivo and in vitro induced by cytotoxic concentrations of the alkylating diabetogenic compound Sz (known to lead to extensive DNA excision repair), no apoptosisspecific features could be identified. Even the early apoptosis marker phosphatidylserine could not be detected on the outer membrane leaflet of islet cells treated with cytotoxic Sz concentrations. Instead, massive necrosis was found to be the predominant type of islet cell death, similar to the results found with $\mathrm{BB}$ rats. The same was found mimicking in vivo inducible NO synthase activity using the NO donor
SNAP. The few cells found to exhibit an apoptotic morphology in vitro probably represent nonendocrine islet cells such as endothelial or duct cells (Fig. 5D). Thus, extensive DNA strand breaks are not exclusively associated with apoptosis but can also be found in necrotic islet cells. As during necrosis, the integrity of intracellular compartments is disrupted and inappropriate activation of various enzymes (eg, intranuclear DNase) could well explain the DNA damage found in necrotic islet cells.

Apoptosis and necrosis, respectively, are by definition two extremes of a continuum of possible types of cell demise. It seems that the availability of ATP is decisive for the mode of cell death (Leist et al, 1997). In particular, DNA-damaging compounds lead to activation of the energy-consuming DNA repair machinery in cells and thus to a depletion of cellular NAD ${ }^{+}$ and ATP pools. As a consequence cells are no longer able to perform the energy-requiring molecular and structural changes necessary for apoptosis, and necrosis will occur instead (Ha and Snyder, 1999). Indeed, within 5 minutes of NO treatment, a massive drop of the islet cell ATP content has been found (Drews et al, 2000); and in islet cells treated with cytotoxic Sz concentrations, extensive exhaustion of their $\mathrm{NAD}^{+}$and ATP pools caused by PARP activation during DNA repair occurs (Burkart et al, 1999). During 
apoptosis, cleavage and thus inactivation of PARP is an early event (Nicholson et al, 1995; Tewari et al, 1995). We did not find any evidence for PARP cleavage after treatment of islet cells with cytotoxic NO concentrations. In contrast we found increased amounts of intact PARP, which indicated ongoing DNA repair. Indeed, in various cell types, a narrow range of ATP depletion (15-25\% of basal levels) has been found to represent a threshold that determines whether a cell dies by apoptosis or by necrosis, and below this threshold necrosis is the dominant cell death pathway (Lelli et al, 1998; Lieberthal et al, 1998). It seems that DNA damage in islet cells leads to extensive PARP activity and thus to a rapid consumption of $\mathrm{NAD}^{+}$and ATP, which subsequently leads to a necrotic mode of islet cell death in vitro.

In conclusion, our results show that detection of DNA strand breaks is not a suitable method to differentiate between apoptosis and necrosis in isolated islet cells or on islet tissue sections. In addition, primary rat islet cells treated with cytotoxic concentrations of $\mathrm{Sz}$ or $\mathrm{NO}$ do not show apoptotic features. Although we cannot exclude that a low percentage of islet cells may undergo apoptosis during manifestation of IDDM, our data demonstrate that necrosis is by far the predominant islet cell death pathway during disease development in BBdp rats. The apparent tendency of islet cells to ultimately die via necrosis may increase the chronic inflammatory process and may thus drive infiltration and activation of immunocytes, a prominent event repeatedly found in islets of freshly diagnosed IDDM patients (Bottazzo et al, 1985; Gepts, 1965; Hänninen et al, 1992; Itoh et al, 1993).

\section{Materials and Methods}

\section{Materials}

Collagenase from Clostridium histolyticum, PI, and Eto were obtained from Sigma (Deisenhofen, Germany); trypsin, Sz, rabbit PARP antiserum, and all reagents for in situ nick translation were from Roche (Mannheim, Germany). The NO donor SNAP was synthesized as described (Fehsel et al, 1996).

\section{Animals}

Male Wistar rats $(200 \mathrm{gm})$ and NMRI mice from the University breeding facility received a standard diet (Sniff-R; Sniff, Soest, Germany) and tap water ad libitum. BBdp rats were purchased from the Möllegard Center (Lille-Skensved, Denmark). Pancreata of C57/ BL6 mice treated with a high dose of Sz $(200 \mathrm{mg} / \mathrm{kg}$ body weight) were a generous gift from Dr. Lampeter (Diabetes Research Institute, Düsseldorf, Germany).

\section{Isolation and Culture of Cells}

Pancreatic islet cells from male Wistar rats were isolated as described (Appels et al, 1989). Briefly, islets were isolated by ductal injection of collagenase $(0.37 \mathrm{U} / \mathrm{mg}, 1.5 \mathrm{mg} / \mathrm{ml}$ in HBSS). After 45 minutes at $37^{\circ} \mathrm{C}$, islets were enriched by centrifugation on a
Ficoll 400 density gradient, handpicked, and dissociated into single cells by trypsin $(2.5 \mathrm{mg} / \mathrm{ml})$ in $\mathrm{Ca}^{2+} /$ $\mathrm{Mg}^{2+}$-free HBSS. Isolated islet cells were allowed to recover for 18 hours in RPMI 1640/10\% FCS. Thymocytes were harvested by gently pressing thymi of 30-day-old NMRI mice against a fine steel wire net submerged in HBSS and were suspended in RPMI/ $10 \%$ FCS as described (Fehsel et al, 1995). Encapsulation of rat islets in alginate beads was performed as described (Bergmann et al, 1992).

\section{Electron Microscopy}

Islet cells $\left(5 \times 10^{4}\right)$ were cultured in microsample tubes as described (Kröncke et al, 1993). Cells, islets, or small pancreatic pieces from BBdp rats were fixed with $1 \%$ glutaraldehyde and $1.5 \% \mathrm{OsO}_{4}$, dehydrated in ethanol, and embedded in Epoxy resin. Ultrathin sections stained with uranyl acetate and lead citrate were examined in a Philips EM 400 electron microscope. Islet cells and nonendocrine cells were distinguished by the presence or absence of hormonecontaining granules.

\section{Determination of DNA Strand Breaks}

To detect DNA strand breaks at the single cell level, the in situ nick translation method was performed as described (Fehsel et al, 1991). Briefly, cryostat sections were dried and fixed in acetone for 10 minutes. Endogenous peroxidase activity was inhibited by $0.3 \% \mathrm{H}_{2} \mathrm{O}_{2}$ in methanol for 30 minutes. The nick translation reaction was performed for 15 minutes at room temperature in $50 \mathrm{~mm}$ Tris- $\mathrm{HCl}, \mathrm{pH} 7.5$, containing $5 \mathrm{U} / 100 \mu \mathrm{l}$ of Kornberg polymerase, $5 \mathrm{~mm} \mathrm{MgCl}_{2}$, $0.1 \mathrm{~mm}$ dithiothreitol, and $3 \mu \mathrm{m}$ each of biotin-dUTP, dGTP, dCTP, and dATP. Slides were washed in PBS and processed for immunocytochemical detection of biotin using horseradish peroxidase-coupled streptavidin (Vectastain Kit; Camon, Wiesbaden, Germany) and diaminobenzidine staining. For analysis of DNA fragmentation by gel electrophoresis, DNA from $4 \times$ $10^{4}$ islet cells was isolated by salt-chloroform extraction and labeled by in situ nick translation as described above. After heating for 5 minutes at $65^{\circ} \mathrm{C}$ and electrophoresis in $1.2 \%$ agarose gels, the DNA was blotted on Hybond-N membrane (Amersham, Braunschweig, Germany). The DNA was visualized on $\mathrm{x}$-ray films by the ECL system (Pierce, St. Augustin, Germany) after incubation with horseradish peroxidase-coupled streptavidin.

\section{Western Blot Analysis}

Cells $\left(10^{6}\right)$ were collected by centrifugation and resuspended in lysis buffer (33 mm Tris- $\mathrm{HCl}, \mathrm{pH}$ 8.0, 33 mm glucose, $6 \mathrm{~mm}$ EDTA, $0.6 \mathrm{~mm}$ phenylmethylsulfonyl fluoride, $2 \mathrm{~m}$ urea, 2\% 2-mercaptoethanol, 1\% SDS). Samples were incubated for 15 minutes at $65^{\circ} \mathrm{C}$ before loading on $8 \%$ SDS-polyacrylamide gels. After electrophoresis, separated proteins were transferred to nylon membranes. Staining with amido black ensured that comparable amounts of proteins were 
loaded. Blots were incubated in $50 \mathrm{~mm}$ Tris- $\mathrm{HCl}, \mathrm{pH}$ 8.0, $150 \mathrm{~mm} \mathrm{NaCl}, 0.3 \%$ Tween $20(\mathrm{v} / \mathrm{v})$, and 5\% dry milk for 1 hour and then overnight with the PARP antiserum (final dilution 1:2000). After washing with PBS/1\% Tween, blots were incubated with peroxidase-conjugated secondary antibody (final dilution 1:1000) for 1 hour and washed with PBS/1\% Tween. Detection was performed by chemiluminescence using the ECL Supersignal System (Pierce) and exposure to $\mathrm{x}$-ray films (Hyperfilm; Amersham).

\section{Annexin V-Binding Assay}

Cells $\left(10^{4}\right)$ were labeled with annexin V-FITC (ApotestFITC; BRAND, Maastricht, Netherlands) and PI and analyzed by flow cytometry using a FACScan (Becton Dickinson, Heidelberg, Germany). At an early stage of apoptosis, phosphatidylserine residues are translocated from the inner to the outer face of the plasma membrane; the FITC conjugate of annexin $\mathrm{V}$, a protein with a high affinity for phosphatidylserines, stains these cells. Simultaneously added PI is excluded from apoptotic cells because of their intact plasma membrane, whereas plasma membrane-permeable necrotic cells are stained by both annexin V-FITC and PI.

\section{Acknowledgements}

The authors thank K. L. Meyer (Institute of Pediatrics, Heinrich-Heine-University of Düsseldorf) for flow cytometry analysis and C. Wilkens-Roth for excellent technical assistance.

\section{References}

Ankarcrona M, Dypbukt JM, Brune B, and Nicotera P (1994). Interleukin-1 beta-induced nitric oxide production activates apoptosis in pancreatic RINm5F cells. Exp Cell Res 213:172177.

Appels B, Burkart V, Kantwerk-Funke G, Funda J, KolbBachofen V, and Kolb H (1989). Spontaneous cytotoxicity of macrophages against pancreatic islet cells. J Immunol 142: 3803-3808.

Aughsteen AA (2000). An ultrastructural study on the effect of streptozotocin on the islets of Langerhans in mice. J Electron Microsc (Tokyo) 49:681-690.

Augstein P, Elefanty AG, Allison J, and Harrison LC (1998). Apoptosis and beta-cell destruction in pancreatic islets of NOD mice with spontaneous and cyclophosphamideaccelerated diabetes. Diabetologia 41:1381-1388.

Barker RN, Erwig L, Pearce WP, Devine A, and Rees AJ (1999). Differential effects of necrotic or apoptotic cell uptake on antigen presentation by macrophages. Pathobiology 67 : 302-305.

Bergmann L, Kröncke KD, Suschek C, Kolb H, and KolbBachofern V (1992). Cytotoxic action of IL-1 beta against pancreatic islets is mediated via nitric oxide formation and is inhibited by NG-monomethyl-L-arginine. FEBS Lett 299:103106.

Bottazzo GF, Dean BM, McNally JM, MacKay EH, Swift PG, and Gamble DR (1985). In situ characterization of autoim- mune phenomena and expression of HLA molecules in the pancreas in diabetic insulitis. N Engl J Med 313:353-360.

Burkart V, Wang ZQ, Radons J, Heller B, Herceg Z, Stingl L, Wagner EF, and Kolb H (1999). Mice lacking the poly(ADPribose) polymerase gene are resistant to pancreatic beta-cell destruction and diabetes development induced by streptozocin. Nat Med 5:314-319.

Cardinal JW, Margison GP, Mynett KJ, Yates AP, Cameron DP, and Elder RH (2001). Increased susceptibility to streptozotocin-induced beta-cell apoptosis and delayed autoimmune diabetes in alkylpurine-DNA-N-glycosylasedeficient mice. Mol Cell Biol 21:5605-5613.

Delaney CA, Pavlovic D, Hoorens A, Pipeleers DG, and Eizirik DL (1997). Cytokines induce deoxyribonucleic acid strand breaks and apoptosis in human pancreatic islet cells. Endocrinology 138:2610-2614.

Di Matteo MA, Loweth AC, Thomas S, Mabley JG, Morgan NG, Thorpe JR, and Green IC (1997). Superoxide, nitric oxide, peroxynitrite and cytokine combinations all cause functional impairment and morphological changes in rat islets of Langerhans and insulin secreting cell lines, but dictate cell death by different mechanisms. Apoptosis 2:164177.

Drews G, Kramer C, and Krippeit-Drews P (2000). Dual effect of $\mathrm{NO}_{\text {on } \mathrm{K}^{+}}{ }_{\text {ATP }}$ current of mouse pancreatic B-cells: Stimulation by deenergizing mitochondria and inhibition by direct interaction with the channel. Biochim Biophys Acta 1464:6268.

Dunger A, Augstein P, Schmidt S, and Fischer U (1996). Identification of interleukin 1-induced apoptosis in rat islets using in situ specific labelling of fragmented DNA. J Autoimmun 9:309-313.

Eizirik DL and Darville MI (2001). Beta-cell apoptosis and defense mechanisms: Lessons from type 1 diabetes. Diabetes 50(Suppl 1):S64-S69.

Fadok VA, Bratton DL, Konowal A, Freed PW, Westcott JY, and Henson PM (1998). Macrophages that have ingested apoptotic cells in vitro inhibit proinflammatory cytokine production through autocrine/paracrine mechanisms involving TGF-beta, PGE ${ }_{2}$, and PAF. J Clin Invest 101:890-898.

Fearnhead HO, Chwalinski M, Snowden RT, Ormerod MG, and Cohen GM (1994). Dexamethasone and etoposide induce apoptosis in rat thymocytes from different phases of the cell cycle. Biochem Pharmacol 48:1073-1079.

Fehsel K, Kolb-Bachofen V, and Kolb H (1991). Analysis of TNF alpha-induced DNA strand breaks at the single cell level. Am J Pathol 139:251-254.

Fehsel K, Kröncke KD, and Kolb-Bachofen V (1996). Assay for detection of nitric oxide-induced apoptosis. Methods Enzymol 269:426-434.

Fehsel K, Kröncke KD, Meyer KL, Huber H, Wahn V, and Kolb-Bachofen V (1995). Nitric oxide induces apoptosis in mouse thymocytes. J Immunol 155:2858-2865.

George M, Ayuso E, Casellas A, Costa C, Devedjian JC, and Bosch F (2002). Beta cell expression of IGF-I leads to recovery from type 1 diabetes. J Clin Invest 109:1153-1163.

Gepts W (1965). Pathologic anatomy of the pancreas in juvenile diabetes mellitus. Diabetes 14:619-633. 
Ha HC and Snyder SH (1999). Poly(ADP-ribose) polymerase is a mediator of necrotic cell death by ATP depletion. Proc Natl Acad Sci USA 96:13978-13982.

Hänninen A, Jalkanen S, Salmi M, Toikkanen S, Nikolakaros G, and Simell O (1992). Macrophages, T cell receptor usage, and endothelial cell activation in the pancreas at the onset of insulin-dependent diabetes mellitus J Clin Invest 90:19011910.

Hill DJ, Petrik J, Arany E, McDonald TJ, and Delovitch TL (1999). Insulin-like growth factors prevent cytokine-mediated cell death in isolated islets of Langerhans from pre-diabetic non-obese diabetic mice. J Endocrinol 161:153-165.

Hoorens A, Van de CM, Kloppel G, and Pipeleers D (1996). Glucose promotes survival of rat pancreatic beta cells by activating synthesis of proteins which suppress a constitutive apoptotic program. J Clin Invest 98:1568-1574.

Itoh N, Hanafusa T, Miyazaki A, Miyagawa J, Yamagata K, Yamamoto K, Waguri M, Imagawa A, Tamura S, Inada M, Kawata S, Tarui S, Kono N, and Matsuzawa Y (1993). Mononuclear cell infiltration and its relation to the expression of major histocompatibility complex antigens and adhesion molecules in pancreas biopsy specimens from newly diagnosed insulin-dependent diabetes mellitus patients. $\mathrm{J}$ Clin Invest 92:2313-2322.

Iwahashi H, Hanafusa T, Eguchi Y, Nakajima H, Miyagawa J, Itoh N, Tomita K, Namba M, Kuwajima M, Noguchi T, Tsujimoto Y, and Matsuzawa Y (1996). Cytokine-induced apoptotic cell death in a mouse pancreatic beta-cell line: Inhibition by Bcl-2. Diabetologia 39:530-536.

Kaneto H, Fujii J, Seo HG, Suzuki K, Matsuoka T, Nakamura M, Tatsumi H, Yamasaki Y, Kamada T, and Taniguchi N (1995). Apoptotic cell death triggered by nitric oxide in pancreatic beta-cells. Diabetes 44:733-738.

Kerr JFR (1995). Neglected opportunities in apoptosis research. Trends Cell Biol 5:55-57.

Kolb-Bachofen V, Epstein S, Kiesel U, and Kolb H (1988). Low-dose streptozocin-induced diabetes in mice: Electron microscopy reveals single-cell insulitis before diabetes onset Diabetes 37:21-27.

Kröncke KD, Brenner HH, Rodriguez ML, Etzkorn K, Noack EA, Kolb H, and Kolb-Bachofen V (1993). Pancreatic islet cells are highly susceptible towards the cytotoxic effects of chemically generated nitric oxide. Biochim Biophys Acta 1182:221-229.

Kurrer MO, Pakala SV, Hanson HL, and Katz JD (1997). Beta cell apoptosis in T cell-mediated autoimmune diabetes. Proc Natl Acad Sci USA 94:213-218.

Lally FJ, Ratcliff H, and Bone AJ (2001). Apoptosis and disease progression in the spontaneously diabetic BB/S rat. Diabetologia 44:320-324.

Leist $M$, Single B, Castoldi AF, Kuhnle S, and Nicotera P (1997). Intracellular adenosine triphosphate (ATP) concentration: A switch in the decision between apoptosis and necrosis. J Exp Med 185:1481-1486.

Lelli JL Jr, Becks LL, Dabrowska MI, and Hinshaw DB (1998). ATP converts necrosis to apoptosis in oxidant-injured endothelial cells. Free Radic Biol Med 25:694-702.

Lieberthal W, Menza SA, and Levine JS (1998). Graded ATP depletion can cause necrosis or apoptosis of cultured mouse proximal tubular cells. Am J Physiol 274:F315-F327.
Like AA, Appel MC, Williams RM, and Rossini AA (1978). Streptozotocin-induced pancreatic insulitis in mice: Morphologic and physiologic studies. Lab Invest 38:470-486.

Liu D, Darville M, and Eizirik DL (2001). Double-stranded ribonucleic acid (RNA) induces beta-cell Fas messenger RNA expression and increases cytokine-induced beta-cell apoptosis. Endocrinology 142:2593-2599.

Lupi R, Dotta F, Marselli L, Del Guerra S, Masini M, Santangelo C, Patane G, Boggi U, Piro S, Anello M, Bergamini E, Mosca F, Di Mario U, Del Prato S, and Marchetti P (2002). Prolonged exposure to free fatty acids has cytostatic and pro-apoptotic effects on human pancreatic islets: Evidence that beta-cell death is caspase mediated, partially dependent on ceramide pathway, and $\mathrm{Bcl}-2$ regulated. Diabetes 51: 1437-1442.

Mauricio D and Mandrup-Poulsen T (1998). Apoptosis and the pathogenesis of IDDM: A question of life and death. Diabetes 47:1537-1543.

Morgan NG, Cable HC, Newcombe NR, and Williams GT (1994). Treatment of cultured pancreatic B-cells with streptozotocin induces cell death by apoptosis. Biosci Rep 14: 243-250.

Nicholson DW, Ali A, Thornberry NA, Vaillancourt JP, Ding CK, Gallant M, Gareau Y, Griffin PR, Labelle M, Lazebnik YA, et al (1995). Identification and inhibition of the ICE/CED-3 protease necessary for mammalian apoptosis. Nature 376 : 37-43.

O'Brien BA, Harmon BV, Cameron DP, and Allan DJ (1996). Beta-cell apoptosis is responsible for the development of IDDM in the multiple low-dose streptozotocin model. J Pathol 178:176-181.

O'Brien BA, Harmon BV, Cameron DP, and Allan DJ (1997). Apoptosis is the mode of beta-cell death responsible for the development of IDDM in the nonobese diabetic (NOD) mouse. Diabetes 46:750-757.

Papaccio G, Linn T, Federlin K, Volkman A, Esposito V, and Mezzogiorno V (1991). Further morphological and biochemical observations on early low dose streptozocin diabetes in mice. Pancreas 6:659-667.

Petrik J, Arany E, McDonald TJ, and Hill DJ (1998). Apoptosis in the pancreatic islet cells of the neonatal rat is associated with a reduced expression of insulin-like growth factor II that may act as a survival factor. Endocrinology 139:2994-3004.

Pipeleers D, Hoorens A, Marichal-Pipeleers M, Van de CM, Bouwens L, and Ling Z (2001). Role of pancreatic beta-cells in the process of beta-cell death. Diabetes 50 (Suppl 1):S52S57.

Saini KS, Thompson C, Winterford CM, Walker NI, and Cameron DP (1996). Streptozotocin at low doses induces apoptosis and at high doses causes necrosis in a murine pancreatic beta cell line, INS-1. Biochem Mol Biol Int 39: 1229-1236.

Sainio-Pöllänen S, Erkkilä S, Alanko S, Hänninen A, Pöllänen $P$, and Simell O (1998). The role of Fas ligand in the development of insulitis in nonobese diabetic mice. Pancreas 16:154-159.

Saldeen J (2000). Cytokines induce both necrosis and apoptosis via a common Bcl-2- inhibitable pathway in rat insulinproducing cells. Endocrinology 141:2003-2010. 
Scaglia L, Smith FE, and Bonner-Weir S (1995). Apoptosis contributes to the involution of beta cell mass in the post partum rat pancreas. Endocrinology 136:5461-5468.

Scarim AL, Arnush M, Blair LA, Concepcion J, Heitmeier MR, Scheuner D, Kaufman RJ, Ryerse J, Buller RM, and Corbett JA (2001). Mechanisms of beta-cell death in response to double-stranded (ds) RNA and interferon-gamma: dsRNAdependent protein kinase apoptosis and nitric oxidedependent necrosis. Am J Pathol 159:273-283.

Steinman RM, Turley S, Mellman I, and Inaba K (2000). The induction of tolerance by dendritic cells that have captured apoptotic cells. J Exp Med 191:411-416.

Tewari M, Quan LT, O'Rourke K, Desnoyers S, Zeng Z, Beidler DR, Poirier GG, Salvesen GS, and Dixit VM (1995). Yama/CPP32 beta, a mammalian homolog of CED-3, is a CrmA-inhibitable protease that cleaves the death substrate poly(ADP-ribose) polymerase. Cell 81:801-809.
Trincavelli ML, Marselli L, Falleni A, Gremigni V, Ragge E, Dotta F, Santangelo C, Marchetti P, Lucacchini A, and Martini C (2002). Upregulation of mitochondrial peripheral benzodiazepine receptor expression by cytokine-induced damage of human pancreatic islets. J Cell Biochem 84:636-644.

Voll RE, Herrmann M, Roth EA, Stach C, Kalden JR, and Girkontaite I (1997). Immunosuppressive effects of apoptotic cells. Nature 390:350-351.

Wiegand F, Kröncke KD, and Kolb-Bachofen V (1993). Macrophage-generated nitric oxide as cytotoxic factor in destruction of alginate-encapsulated islets: Protection by arginine analogs and/or coencapsulated erythrocytes. Transplantation 56:1206-1212. 